\title{
The Consequences of a Work-Family (Im)balance: From the Point of View of Employers and Employees
}

\author{
Nina Tomaževič ${ }^{1}$, Tatjana Kozjek ${ }^{1}$ \& Janez Stare $^{1}$ \\ ${ }^{1}$ Faculty of Administration, University of Ljubljana, Ljubljana, Slovenia \\ Correspondence: Nina Tomaževič, Faculty of Administration, University of Ljubljana, Gosarjeva ulica 5, 1000 \\ Ljubljana, Slovenia. Tel: 386-1-580-5400. E-mail: nina.tomazevic@ @u.uni-lj.si
}

Received: May 13, 2014

Accepted: May 26, 2014

Online Published: July 25, 2014

doi:10.5539/ibr.v7n8p83

URL: http://dx.doi.org/10.5539/ibr.v7n8p83

\begin{abstract}
Finding the right balance between the different spheres of life of an individual, especially in the case of balancing work and family, requires a variety of measures and good cooperation from all stakeholders-employees, employers, trade unions, local communities and the state. A work-family balance (WFB) has a number of positive consequences, while an imbalance will have negative consequences for both employees and the organisations and society in general. The aim of this paper is to present the results of two studies comparing the positive consequences of WFB and the negative consequences of a work-family imbalance as perceived by employers and employees in Slovenia. The results of the surveys showed, firstly, that employers and employees recognize similar (but not identical) consequences of WFB, secondly, that the WFB of employees is better in companies where both stakeholders share a similar perception of consequences, and thirdly, that the perception of negative consequences of poor WFB differs the most between the organizations offering employees good possibilities for WFB and the organizations in which managers invested little or no effort in helping their employees balance their work and family lives.
\end{abstract}

Keywords: work-family balance, employers, employees, stress, absenteeism, employee satisfaction

\section{Introduction}

\subsection{The Significance of Work-Life and Work-Family Balance}

Work/life issues impact everyone, regardless of education level, gender, income level, family structure, occupation, race, age, job status or religion (McMillan, et al., 2011). Globalisation, new technologies and business restructuring are challenging long-established patterns of paid work and at the same time, imposing new burdens on families, individuals and households (Taylor, 2003). Considerable changes in labour force demographics and family composition have taken place in the past few decades, making the challenge of adequately balancing work and family roles one of today's central concerns for individuals (Valcour, 2007).

According to Littig (2008), the notion 'work-life balance' (WLB) has been promoted since the beginning of the nineties, when human resource managers, especially those from large organisations, became aware of an increase in the rate of burn-out syndrome in their personnel and the need and desires of (female) employees to reconcile family and work. The purpose of promoting WLB was to provide a win-win situation for both sides (employees and employers). The argument was: A balanced relationship between work life and private life reduces stress while increasing personnel's overall satisfaction and quality of life, thereby increasing the efficiency of work.

The importance of work-family balance (WFB) has moved into the foreground in the last decades, above all, as a result of the growing number of families in which both partners work (Gray \& Tudball, 2002; Schmiedel, 2011), the ageing population (Lockwood, 2003; Knaflič, et al. 2010), long working days, and stress both in the workplace and in connection with balancing work and free time, spending time with the family and the spending of free time in a satisfying manner. This applies to both women and men (Levin-Epstein, 2006). An increasing number of individuals face a dual set of obligations - the requirements of the workplace and family obligations. Not only that, the numerous roles of the individual in today's complex and fast-paced world do not exclude each other, but instead overlap (Bourne, et al. 2009). In the workplace the individual is a person who orders products/services, a supplier, a colleague, a boss, a subordinate, while at home he or she also has plays the role of a partner, parent, sibling, child, friend, pet owner, etc. The various roles individuals play have traditionally 
been viewed as opposing, implicitly suggesting that attention to one area of a person's life necessarily detracts from the others, and that juggling and managing multiple roles causes stress and emotional strain (Lockwood, 2003).

Work-family balance is therefore a complex field, since it does not only relate to challenges faced by parents with children. Rather, it concerns everyone whose environment includes individuals in need of special care and assistance, including the sick and/or elderly. Finding a balance between different areas of life requires a range of measures and good cooperation by both employees, organisations and trade unions, and the state and local communities (Doorne-Huiskes, Remery \& Schippers, 2003, COFACE, 2008). All parties involved must be aware of the existence of the problem related to balancing work and family lives, and of their responsibilities in addressing it.

The result of the increasing difficulty of balancing work and family lives is the increasing frequency of people starting families at a later age, a decrease in the number of children or people with no children at all. Alternatively, some parents may choose to temporarily or permanently stop working. Children whose parents do not work are more likely to be poor, whereas mothers who have interrupted their careers to care for their children are exposed to a higher risk of poverty in later life. Finding a good work-family balance is thus a critical issue for the well-being of children and society, as both poverty and a lack of personal attention can harm child development (OECD, 2008).

In times of economic crisis, many employers plead a lack of resources for the promotion of activities favouring work-family balance and rapidly reduce labour costs and dismiss workers. Such measures are, however, short-term in nature and bring with them numerous costs associated with social hardship. Although some work-family balance measures are not expensive, many do, however, involve some costs. When undertaking the cost-benefit analysis of such measures, an immediate short-term focus on costs must be carefully weighted and balanced against longer-term benefits for the employer (ILO, 2004; Kisilewitz \& Bedington, 2009).

Reconcilation of work and private/family lives is a key element in the quality of work and employment, meriting a mention in the Europe 2020 strategy (European Commission, 2010; Aristovnik \& Pungartnik, 2009).

\subsection{Definition of Work-Life and Work-Family Balance}

Work-life balance (WLB) means effectively combining working life with private obligations or aspirations (Littig, 2008). According to Taylor (2003), there are many different definitions of the term work-life balance. He argues that 'balance' is presumed to exist between the paid work we perform and the lives we lead outside our job. But in reality, life and work overlap and interact. According to Lockwood (2003) and McMillan, Morris \& Atchley (2012) WLB has different meanings depending on the context in which it is used. There are different terms and definitions used in connection to WLB, such as work/life, work/family, work/family balance, work/family conflict, family-friendly benefits, work/life programs, work/life initiatives, work/family culture, boundary crossing, work-life harmony, etc.

WLB ranges from a narrow understanding of WLB primarily addressing the reconciliation of work and family lives to an expanded understanding including health care, (further) training and life-long learning. Work/life initiatives can potentially deal with a wide range of issues including: on-site childcare, emergency childcare assistance, seasonal childcare programs (such as March Break or Christmas), eldercare initiatives (comprising referral programs, eldercare assessment, case management, local organizations or businesses that can help with information or products, or seminars and support groups), referral programs for care services, local organizations, etc., flexible working arrangements, parental leave for adoptive parents, family leave policies, other leaves of absence policies such as educational leaves, community service leaves, self-funded leaves or sabbaticals, employee assistance programs, on-site seminars and workshops (covering such topics as stress, nutrition, smoking, communication, etc.), internal and/or external educational or training opportunities, fitness facilities, or fitness membership assistance (financial). WLB can be seen in at least three social contexts: increasing participation of women in the labour market, demographic changes and corporate interest regarding flexible labour. Ashforth et. al. (2000) in their 'boundary theory' describe how individuals cross boundaries between the roles of home, work and other social life realms (e.g. health clubs, churches, local bars).

Special attention when talking about WLB is often devoted to employees with children. In continuation, the article will place emphasis on balancing work and family. The representative of traditional efforts to define WFB Frone (2003) contends that balance occurs when there is a 'lack of conflict or interference between the work and family role'. Opponents such as Grzywacz \& Carlson (2007) define WFB as 'the accomplishment of role-related expectations that are negotiated and shared between an individual and his or her role-related partners in work and family domains'. Greenhaus, Collins \& Shaw (2003) define WFB as 'the extent to which individuals are equally 
engaged in - and equally satisfied with - their work and family roles'. They claim that the definition is broad enough so that it includes both positive and negative balances. To this end, balance becomes a continuum with imbalance (in either role) anchoring one end and balancing (again in either role) the other end. Later, Greenhaus and Allen (2011) states that WFB has to be defined from a custom-tailored perspective; i.e. as 'the extent to which effectiveness and satisfaction in work and family roles are compatible with an individual's life values at a given point in time'.

Clark (2000) in her 'work-family border theory' explains how individuals balance work and home by reducing role conflict and crossing the borders between these life realms, e.g. receiving family-oriented phone calls at work or taking business calls at home. When the boundaries between the work and family microsystems are sufficiently permeable and flexible, processes occur whereby aspects of the work and family domains influence each other. Some researchers define work-family balance in terms of work-family conflict and facilitation, e.g. Grzywacz \& Bass (2003), stating that work-family conflict maps onto the concept of demands, whereas capabilities are relevant for facilitation. Others have defined WFB as the absence of work-family conflict (Clark 2001; Salzstein, Ting \& Salzstein, 2001).

The Lattice Group (2010) claims that the current WL (and WF) models in the USA are organised around an ideal worker immune from family life and personal needs. But individuals with personal needs and a family often cannot perform as ideal workers. Achieving work-family balance is particularly difficult in the case of single-parent families and in the case of older children who are not yet able to look after themselves; therefore the formulation of a work-family balance policy should take into account all those who are not fully capable of looking after themselves (Švab, 2007; OECD, 2008).

Reconciling work and family lives is thus not only a matter of helping families or women, but a central social issue (Fernández Cordón, 2009). Parasuraman \& Greengaus (2002), Švab (2007) and Thévenon (2008) point out that when reconciling family life and work it is also necessary to take into account the ageing population, meaning that in the future, support should not only be aimed at families with children but also at families caring for elderly relatives.

The majority of studies on WFB are focused on employed men and women who are married or living with a partner or people with children. Single-earner mothers and fathers, single and childless employees with extensive obligations regarding eldercare, blended families with children from both partners' prior marriages, families with shared custody of children and grandparents raising their grandchildren have been omitted from studies (Parasuraman \& Greenhaus, 2002).

\subsection{Purpose of the Study}

The main purpose of our study was to identify whether the consequences of work-family balance or work-family imbalance, as perceived by employees and employers, are identical or different. The goals of the studies presented in the paper were to establish:

- the most evident positive consequences of work-family balance and most evident negative consequences of work-family imbalance as assessed by employers and employees and

- whether any discrepancies in motives for encouraging WFB of employees among organizations existed.

The paper is divided into the following sections. Following the introduction in which the significance and definitions of work-life balance are presented, a brief overview of literature regarding the consequences of work-family (im)balance for employees and employers is presented and supplemented with a description of reasons for encouraging WFB of employees. This is followed by a presentation of the results of the empirical studies conducted among employees and employers (management or HR representatives of organisations) in Slovenia within in the context of the research project 'Improving the Working Environment with Innovative Solutions' (INODEL), which was co-financed by the European Commission from the European Social Fund (ESF). In discussion and conclusion, a summary of the key findings and suggested avenues for further research are presented.

\section{Literature Review: Consequences of Work-Family (Im)Balance and Reasons for the Encouragement of Work Family Balance}

Work-family imbalance has numerous negative consequences for both employees and employers (i.e., organisations), and therefore for the wider community as well (Byron, 2005; Jones, Burke \& Westman, 2005; Haemmig \& Bauer, 2009). On the other hand, a balance in at least the majority of key areas of an individual's life brings significant advantages, both material and non-material, to all involved (Lockwood, 2003; Dallimore \& Mickel, 2006). The literature review will firstly focus on the positive consequences of work-family balance as 
well as on the negative consequences of work-family imbalance and, secondly, on reasons for encouraging work-family balance of employees. Both will represent a theoretical basis for the hypotheses of our study.

\subsection{Positive Consequences of Work-Family Balance and Negative Consequences of Work-Family Imbalance}

Based on numerous studies on work-family (im)balance, researchers have cited various positive consequences of WFB (e. g. Lockwood, 2003; Dallimore \& Mickel, 2006) and negative consequences of work-family imbalance (e.g. Parasuraman \& Greenhaus, 2002; Haemmig \& Bauer, 2009) for both employees and employers. According to Doorne-Huskies, Remery \& Schippers (2003), Lockwood (2003), Taylor (2003), MCYS (2004), Bird (2006), Commission of the European Communities (2008), ILO (2004), Littig (2008), Tariq et al. (2012) family-friendly practices bring with them the following major positive consequences (benefits) for employees:

- decreased stress and burnout caused by reducing conflicts between work and family responsibilities, more leisure time,

- less ill health, both physical and mental and therefore a higher quality of life,

- a more supportive and positive working environment where each person is valued and needed, also contributing to making team work easier and more efficient,

- job satisfaction, increased empowerment, control over the workday, increased passion for work.

The positive consequences that employers can derive from family-friendly practices are also numerous (Dench, et al. 2000; Lockwood, 2003; Casper \& Buffardi, 2004; ILO, 2004; Bird, 2006; Dallimore \& Mickel, 2006; Darmanin, 2006; Dunne \& Teg, 2007; Commission of the European Communities, 2008; Knaflič, et al. 2010):

- reduced absenteeism and lateness,

- reduced staff turnover, which can lower the costs of recruitment, induction and training associated with the replacement of absent employees,

- enhanced capacity to attract a broader range of candidates and retain high-quality employees, both men and women, in a competitive job market (organisational attractiveness),

- enhanced performance and motivation among employees and improve productivity,

- increased efficiency and cost effectiveness resulting from a decrease in downtime or overheads (employees working from their homes),

- improved teamwork, communication and relations between employees and with customers,

- creation and maintenance of a competitive edge and innovation, contributing to improved competitiveness,

- enhanced image of the employer,

- decreased likelihood of unethical business practices,

- increased work motivation, job satisfaction and morale increasing employee job empowerment and commitment, and greater cooperation, loyalty and innovativeness.

Taylor (2003) emphasises that employee commitment can make the difference between those organisations which are able to compete in the market place and those which cannot. The adoption of measures for a better work-family balance involves short-term costs, but in the long term the overall costs of business are reduced as a result of reduced work absenteeism and improved productivity (Doorne-Huskies, Remery \& Schippers, 2003; McGuire, Kenney \& Brashler, 2010).

Many empirical studies have focused on consequences of work-family imbalance which directly influence the employee, e.g. alcohol use, job and life satisfaction, career and family satisfaction, fatigue, exhaustion, depression, psychical ailments (Beutell \& Wittig-Berman, 1999; Boyar, et al., 2003; Jansen, et al., 2003). But there are also those consequences that are related to work behaviours which significantly influence the performance of employers, e.g. absenteeism, leaving work early and tardiness, since they contribute to dysfunctional norms, cause disruption to staffing and cost money (Iverson \& Deery, 2001; Greenhaus, et al., 2001; Kossek, et al., 2001).

As described above, one can see that the positive consequences of WFB activities are usually stated as precisely the opposite of the negative consequences that arise in case if the organisation fails to place sufficient effort in supporting its employees in dealing with work-family conflicts. On the basis of theoretical research on the consequences of work-family (im)balance, we developed the following hypotheses:

H1a: The feeling of stress and overwork/burnout are the most evident negative consequences of work-family 
imbalance.

H1b: A decrease in absenteeism due to sick leave and increased satisfaction are the most evident positive consequences of work-family balance.

The main sources of data (examples of consequences) for the hypotheses, were found in the works of Saltzstein, Ting \& Salzstein (2001), Lockwood (2003), Behson (2005), Bird (2006), Dallimore \& Mickel (2006), Dunne \& Teg (2007), Knaflič et al. (2010). Parasuraman \& Greenhaus (2002) claim that limited research on the positive connections between work and family, and overemphasis on work-family conflict and its negative consequences exist.

\subsection{Reasons for Encouraging WFB of Employees}

There are theoretical and empirical reasons for expecting that by reducing work-family imbalance, a family-supportive work environment would enhance employees' satisfaction with their job, family and life in general (Lapierre, et al., 2008). According to Allen (2001), the more employees perceive their work environment as family-supportive, the less they experience work-family imbalance. Theory and practice also reveal that the differences exist between various organisations in terms of the intensity of motives for encouraging WFB. One would expect the main motive to be the minimisation of negative consequences and maximisation of positive ones. Many of these consequences only appear in the long term and are not directly reflected in financial results. For this reason, particularly in crisis situations, when states, local communities and employers introduce austerity measures, the latter should not only be directed towards the immediate removal of previously acquired rights but also review the advantages of measures that could still be introduced in order to achieve a more effective WFB. It is vital to assess the positive consequences of such measures in the long term, taking into account the crossover and indirect reflection of their effects on all levels of quality of life - health and satisfaction of the population, social conditions, societal relations, etc.

Lockwood (2003), Žaucer-Šefman (2007) and McGuire, Kenney \& Brashler (2010) point out that the costs resulting from discriminatory behaviour towards parenthood in the workplace and work-family imbalance can be extremely high. They divide these into:

- direct costs, e.g. absenteeism, fluctuation, more frequent interruptions of work, abuse of sick time, a poor ratio between time expended and quality of work, more accidents at work, fraud, embezzlement, etc.,

- indirect costs, e.g. job dissatisfaction, distrust, task avoidance, tardiness, low morale, low commitment, mistrust, hostility or aggression.

Other serious repercussions having an effect on society as a whole are depression, alcohol and drug abuse, marital and financial problems, compulsive eating disorders, and employee burnout (Lockwood, 2003). In their research, Nelson/Li/Sorensen/Berkman (2012) found that that a robust relationship between work-family conflict and smoking exists, but that this relationship is dependent upon the total amount of conflict experienced and the direction of the conflict.

Haemmig \& Bauer (2009) report different negative outcomes of work-life imbalance, such as a significantly higher relative risk for poor self-rated health, negative emotions and depression, low energy and optimism, and fatigue and sleep disorders as compared to employees with no work-life conflict. Friedman and Greenhaus (2000) emphasize that working adults learn to build networks of support at home, at work, and in the community. Conflict between work and family has real consequences and significantly affects the quality of family life and career attainment of both men and women. The consequences for women may include serious constraints regarding career choices, limited opportunities for career advancement and success in their work role, and the need to choose between two apparent opposites - an active and satisfying career or marriage and children. Many men have to trade off personal and career values while seeking ways to make a dual-career family work, often requiring them to embrace family roles that are far different, and more egalitarian, than those they learned as children.

According to Lockwood (2003) an employer's commitment to work-family initiatives is influenced by the perception of whether or not such initiatives provide a positive return on investment. In the past decade, employers have increasingly been realizing that the quality of an employee's personal and family life impacts work quality and that there are concrete business reasons to promote work and family integration. The author even suggests five key factors to measure return on investment in work-family programs: (1) employee time saved, (2) employee retention, (3) increased motivation and productivity, (4) absenteeism, (5) decreased health care costs and stress-related illnesses.

From the literature review (i.e., ILO, 2004; Kisilewitz \& Bedington, 2009) it is evident that employers do not take into account wider socially responsible perspectives concerning the consequences of employee work-family 
imbalances, but focus more on cost benefits or return on investment of organisation's regulations referring to this area (Lockwood, 2003). Consequently, it can be expected that employers that widely neglect the area of WFB perceive consequences of work-family imbalance as having a lower impact on the organisation's costs than it can be concluded from actual experience of employees with poor possibilities of WFB. Their focus is more on the near future than on long-term effects. The authors propose several programs/policies to employers to help employees balance their work and family realms, such as flexible work schedules, compressed work weeks, unpaid leave, part-time work, telecommuting, job sharing, onsite child care facilities, family leave, eldercare and stress management and time management workshops (Whittard \& Burgess, 2007; Breaugh \& Frye, 2007; Baxter \& Chesters, 2011).

The possibilities for helping employees balance their work and family lives are therefore numerous. According to Casper, Harris, Taylor-Bianco and Wayne (2011), the social support (emotional support, instrumental support, appraisal support, information support) of employers (managers) is very important in helping employees decrease work-family conflict. The findings regarding the importance of organizational support, i.e. family-friendly policies, offered by employers are also described by other authors, such as Halpern (2005), Hyland, Rowsome \& Rowsome (2005), Morgan et al. (2009) and Sands \& Harper (2007). How employers perceive the need for WFB and the consequences of WF(im)B is therefore crucial. If employers' attitudes to WFB programs and activities or the workplace atmosphere are conservative, WFB implementation is inhibited (Matsuda, Kokumai \& Wang, 2009). De Villiers and Kotze (2003) emphasize that the most significant work-family conflicts arise from complex workplace issues, such as management changes, supervisory and technical competences, and leadership and culture which means that leadership, managerial recognition and support for individuals and their needs strongly influence the work-life balance.

An important aim of our study was to further investigate possible reasons (motives) why WFB of employees in some organizations is not encouraged. First, the perceptions of consequences of WFB between employers and employees were compared in organisations with poor possibilities for WFB and those with good possibilities and, second, the two groups of employers were compared regarding the perception of consequences of WF(im)B.

H2: Employers' and employees' perceptions of consequences of work-family (im)balance differ to a higher extent when comparing employees experiencing poor WFB and organizations with poor possibilities for WFB than when comparing employees experiencing good WFB and organizations with good possibilities for WFB.

H3: Organizations with poor possibilities of WFB and organizations with good possibilities of WFB differ in their perceptions of the consequences of work-family (im)balance.

Some research has already been done regarding the effects of WFB perception on the acceptance of work arrangement requests. Ueda's study (2012) showed that when employers (managers) had a positive perception of the WFB policy, it positively influenced their acceptance of their subordinate's requests regarding support needed for balancing work and family lives. Negative perceptions had a negative impact on the acceptance of requests. Our study went even further, seeking discrepancies in the perception of consequences of WF(im)B between those organizations with good and those organizations with poor possibilities for WFB. This enabled use to seek possible motive(s) for the better or worse situation in organizations regarding support to employees in balancing their work and family lives.

\section{Empirical Research}

\subsection{Research Plan and Methodology}

The research took place in two stages. In the first stage, in February 2011, a questionnaire was e-mailed to $\mathrm{n}$ $=18,175$ organisations across all sectors of the economy in Slovenia that had a published e-mail address either in business directories or on a company website. The response rate was $5.6 \%$; a total of $n=1,009$ organisations responded.

Participation in the survey was as follows:

- $\quad 96.8 \%$ organisations with up to 250 employees and $3.2 \%$ organisations with more than 250 employees (76.6\% of organisations in Slovenia (Note 1) have up to 250 employees, while $23.4 \%$ are larger; $\chi^{2}=227.965 ; \mathrm{p}<$ 0.0001),

- the largest number of organisations were from the Central Slovenia region (35.7\%), followed by the Podravska region (13.7\%) and the Savinjska region (12\%); the regional structure of organisations in the sample does not differ from the statistical population in terms of the three largest regions $\left(\chi^{2}=4.06 ; p=\right.$ $0.255)$, 
- $\quad 91.3 \%$ were limited liability companies and public limited companies, while $8.7 \%$ were organisations of other types (the sample structure is similar to the population structure; $\chi^{2}=0.14 ; p=0.709$ ).

Among the organisations in the sample, the share of large organisations, i.e. organisations with more than 250 employees, was too small compared to the population. The structure of the organisations by region and legal status was similar to the structure of the statistical population.

The representatives of the organisations (employers) who filled in the questionnaire, were, in the largest number of cases, HR officers (34.9\%), followed by directors and/or CEOs (25.3\%), HR managers (17.4\%) and secretaries/assistants (13.1\%).

In the second stage, in June 2011, private- and public-sector employees were invited to complete an online questionnaire. A total of $\mathrm{n}=774$ respondents completed the questionnaire, of whom:

- $53.2 \%$ were men and $46.8 \%$ were women (economically active population of Slovenia: (Note 2) 55\% men, $45 \%$ women; $\chi^{2}=1.94 ; \mathrm{p}=0.164$ ),

- $29.4 \%$ of respondents had secondary education or less, while $71 \%$ had a post-secondary or higher education qualification (working population of Slovenia: $73 \%$ have secondary education or less and $27 \%$ have a post-secondary or higher education qualification; $\chi^{2}=804.09 ; \mathrm{p}<0.0001$ ),

- the age structure of the sample and of the Slovenian population is shown in Fig. $1 ; \chi^{2}=96.53 ; p<0.0001$ ).

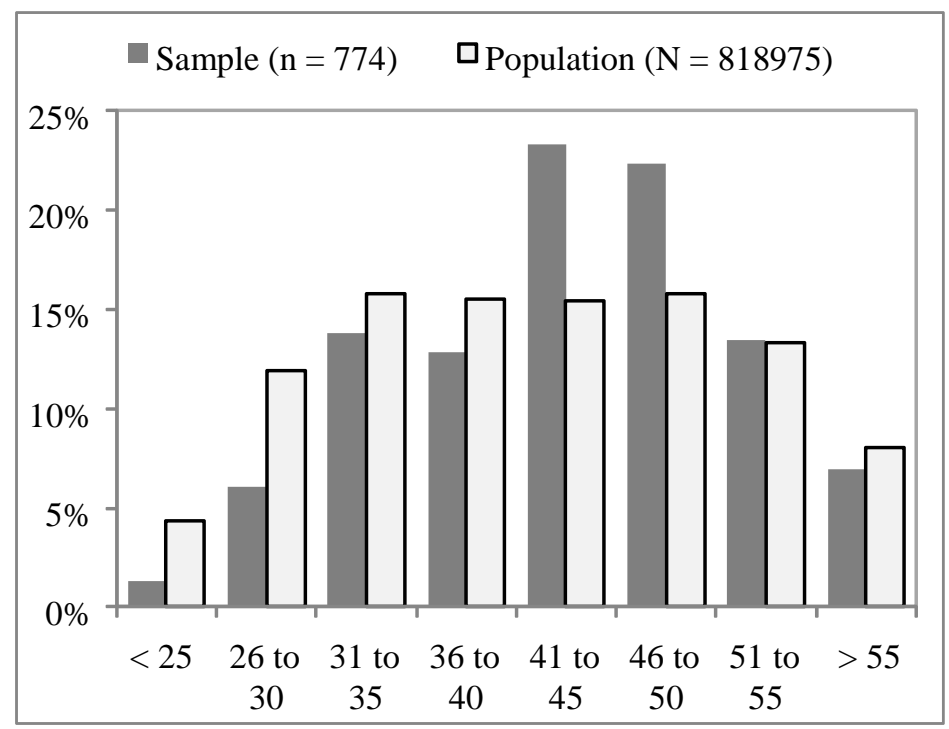

Figure 1. Comparison of population structure and sample structure of economically active population by age

In comparison to the economically active population of Slovenia, the sample included too many people with at least a post-secondary qualification and too few people under the age of 36 .

The following variables were used to test the hypotheses:

- assessment of the actual situation and aspirations in terms of WFB in the following areas $(1=$ very poor; $5=$ excellent):

- flexible working time,

- compressed working week,

- half- or part-time work,

- working from home,

- non-discrimination of women, pregnant women, parents and other groups of employees with greater needs for a better WLB,

- childcare provision for pre-school children and after-school care for school-age children (e.g. school holidays, national holidays),

- paid leave for parents on a child's first day of school, 
- outings or social gatherings for employees' families,

- ability to take time off to care for other/elderly family members or partner,

- child supervision to and from school,

- workshops on time management and stress management,

- the group of respondents, i.e. employers and employees;

- the negative consequences of work-family imbalance, the expressiveness of which is assessed on a 5-point scale $(1=$ negligible, 5 = explicit $)$ - the question for employers was: 'Which are the most evident negative consequences of work-life imbalance?' and the question for employees was: 'To what extent are the enumerated negative consequences of work-life imbalance expressed in your case?':

- stress,

- feeling of overwork/burnout,

- conflicts at work/home,

- health problems - frequent acute illnesses (e.g. cold, fever, headache),

- lengthy sick leave due to chronic illnesses;

- the positive consequences of WFB, the expressiveness of which is assessed on a 5-point scale $(1=$ negligible, $5=$ explicit) - the question for employers was: 'Which are the most evident positive consequences of WFB?' and the question for employees was: 'Which are, in your opinion, the positive consequences of balanced work and family?':

- reduced absence due to sick leave,

- increased employee satisfaction and productivity,

- improved communication among employees,

- greater loyalty to the organisation,

- improved image of the organisation.

Employers' representatives were asked to first assess the actual and optimal WFB of their employees in different areas and secondly, the consequences of work-family (im)balance for their employees. Employees were asked to assess their actual and optimal WFB in different areas and how, in their opinion, the consequences of WFB and imbalance are felt. The consequences were ranked according to average expressiveness within each of the studied group (employers and employees). The differences between expressiveness of consecutive consequences were assessed by Wilcoxon's matched pair test (Appendix A and B) and population rank was assigned to each of the studied consequences.

Since the two stages of the research took place one after the other and did not only include employees of those organisations that responded to the questionnaire in the first stage, the results of the two researches were not directly comparable. In order to be able to compare the responses of employers and employees despite this fact, comparability was ensured by comparing the responses of employees and employers who had similar discrepancy between mean score on assessment of actual situation and aspirations regarding measured areas of WFB. One third $(n=323)$ of the organizations with the lowest discrepancy (values below the 33 percentile) between the actual and optimal situations were regarded as having good possibilities for WFB for employees while the remainder were viewed as having poor possibilities for WFB $(n=662)$. Employees were categorized into two groups according to identical criteria, namely: employees with a mean discrepancy lower than the 33 percentile were regarded as having good WFB $(n=303)$ and the others as having poor WFB $(n=471)$.

In this way we formed two homogeneous groups with regards to the control variable, i.e. the evaluated discrepancy between the actual and optimal situation for areas of WFB.

The second hypothesis was tested through a comparison of results of using a multivariate logistic regression within each formed group of employees and employers, treating the assessment of consequences as independent and group membership (employer or employee) as a dependent variable.

The third hypothesis compared the evaluation of consequences between employers' representatives of organizations with good possibilities for WFB and representatives of organizations with poor possibilities for WFB for their employees. The hypothesis comprises several sub-hypotheses with the two groups of representatives of the organizations compared against each of the measured consequences. A set of 
Mann-Whitney $\mathrm{U}$ tests was used to test the significance of the differences in assessment of each consequence of WFB between the two groups. All hypotheses were tested at the level $=0.05$ (two-tailed).

\subsection{Results}

Absolute ranks of consequences by expressiveness for sample (column S) and population (column P) for employers and employees are given in Table 1. Consequences that were assessed similarly (no significant difference in expressiveness were found) were given the same population rank.

Employers assessed that the most important negative consequence of work-family imbalance for employees is feeling of burnout, followed by stress. Employees, on the other hand, perceive burnout, stress and conflicts at work/home as equally important consequences of imbalance. Hypothesis H1a can be partially supported as feeling of burnout and stress are the most important consequences of work-family imbalance from employees' and employers' point of view, however conflicts at work and/or at home also tend to manifest themselves more frequently when imbalance is present. Interestingly illnesses (acute or chronic) are perceived as less important from both parties.

According to employers, WFB is manifested positively primarily in reduced absence from work due to the sick leave, secondarily by increased satisfaction and productivity of employees and thirdly in improved communication between employees.

Table 1. Consequences of work-family (im)balance: employers vs. employees

\begin{tabular}{|c|c|c|c|c|c|c|}
\hline & \multirow{2}{*}{$\begin{array}{c}\text { Employers } \\
\text { Mean (Me; SD) }\end{array}$} & \multicolumn{2}{|c|}{ Rank } & \multirow{2}{*}{$\begin{array}{c}\text { Employees } \\
\text { Mean (Me; SD) }\end{array}$} & \multicolumn{2}{|c|}{ Rank } \\
\hline & & $\mathrm{S}$ & $\mathrm{P}$ & & $\mathrm{S}$ & $\mathrm{P}$ \\
\hline \multicolumn{7}{|l|}{ Negative consequences of imbalance } \\
\hline Stress & $3.26(4 ; 0.91)$ & 2 & 2 & $2.99(3 ; 1.37)$ & 2 & 2 \\
\hline Feeling of overwork/burnout & $3.27(4 ; 0.93)$ & 1 & 1 & $3.05(3 ; 1.35)$ & 1 & 2 \\
\hline Conflicts at work/home & $2.85(3 ; 0.93)$ & 3 & 3.5 & $2.93(3 ; 0.94)$ & 3 & 2 \\
\hline Health problems - frequent acute illnesses & $1.88(2 ; 1)$ & 5 & 5 & $2.85(3 ; 1.42)$ & 4 & 4 \\
\hline Lengthy sick leave due to chronic illnesses & $2.82(3 ; 1)$ & 4 & 3.5 & $1.55(1 ; 1.06)$ & 5 & 5 \\
\hline \multicolumn{7}{|l|}{ Positive consequences of balance } \\
\hline Improved image of the organisation & $3(3 ; 0.82)$ & 5 & 5 & $3.55(4 ; 0.53)$ & 4 & 4 \\
\hline Improved communication between employees & $3.5(4 ; 0.96)$ & 3 & 3 & $4.49(5 ; 0.78)$ & 2 & 2 \\
\hline Reduced absenteeism due to sick leave & $4.21(4 ; 0.91)$ & 1 & 1 & $3.88(4 ; 1.11)$ & 3 & 3 \\
\hline Increased employee satisfaction and productivity & $3.65(4 ; 1.1)$ & 2 & 2 & $4.52(5 ; 0.64)$ & 1 & 1 \\
\hline Greater loyalty to the organisation & $3.22(3 ; 1.19)$ & 4 & 4 & $3.59(4 ; 0.62)$ & 5 & 5 \\
\hline
\end{tabular}

Source: Research 2011.

Employees perceive increased satisfaction and productivity as most important consequence of WFB, followed by improved communication at work and reduced absenteeism due to sick leave. Hypothesis H1b can be partially supported as employee satisfaction is one of the most important positive consequences of WFB along with reduced absenteeism. Communication between employees, however, seems to improve also when WFB of employees is achieved.

Both groups place the image of the organisation and loyalty to the organisation in the last two places in terms of expressiveness.

The results of the second (H2) hypotheses testing are shown in Table 2 and 3. Perception of consequences of two homogenous groups is compared. The left-hand side of the table compares the perception of consequences of employers who rated the possibilities of WFB of their employees as poor against the perception of employees with poor WFB while the right-hand side compares the perception of consequences of WFB between employers who assessed the possibilities of WFB of their employees as good against the perception of employees experiencing good WFB. Odds ratios above 1 indicate consequences employees assign higher importance to, while ratios below 1 indicate consequences employers assign higher importance to. 
Table 2. Results of logistic regression; OR - odds ratio; CI - confidence interval (OR $<1$ - employers agree more with the claim; OR > $1-$ employees agree more with the claim)

\begin{tabular}{lcc}
\hline Reference group: employers & POOR WFB & GOOD WFB \\
\hline Negative consequences of imbalance & OR $(95 \% \mathrm{CI})$ & OR $(95 \% \mathrm{CI})$ \\
Stress & $0.67^{* * *}(0.53 ; 0.85)$ & $0.76(0.55 ; 1.05)$ \\
Feeling of overwork/burnout & $0.69^{* * *}(0.55 ; 0.88)$ & $0.67 *(0.49 ; 0.92)$ \\
Conflicts at work/home & $1.53^{* * *(1.15 ; 2.04)}$ & $2.2 * * *(1.45 ; 3.34)$ \\
Health problems - frequent acute illnesses & $3.91^{* * *}(3.03 ; 5.03)$ & $3.3 * * *(2.36 ; 4.61)$ \\
Lengthy sick leave due to chronic illnesses & $0.28^{* * *}(0.22 ; 0.35)$ & $0.19^{* * *}(0.14 ; 0.27)$ \\
Positive consequences of balance & & $1.03(0.65 ; 1.63)$ \\
Improved image of the organisation & $1.63^{* * *(1.16 ; 2.31)}$ & $2.79 * * *(1.88 ; 4.12)$ \\
Improved communication between employees & $3.98^{* * *}(2.84 ; 5.58)$ & $0.25 * * *(0.17 ; 0.38)$ \\
Reduced absence due to sick leave & $0.17^{* * *}(0.12 ; 0.24)$ & $2.6 * * *(1.55 ; 4.35)$ \\
Increased employee satisfaction and productivity & $3.67 * * *(2.44 ; 5.5)$ & $0.74(0.47 ; 1.17)$ \\
Greater loyalty to the organisation & $0.5 * * *(0.35 ; 0.72)$ &
\end{tabular}

$* \mathrm{p}<0.05, * * \mathrm{p}<0.01, * * * \mathrm{p}<0.001$.

Source: Research 2011.

\subsubsection{Organizations and Employees with Poor Possibilities of Work-Family Balance}

Organisations with poor possibilities of work-family balance and employees experiencing work-family imbalance themselves, significantly differ in their perception of all consequences of such a state as well as the consequences of good WFB. Consequences on which employers placed more emphasis are all of a long-term nature or such that their impact cannot be assessed directly. Lengthy sick leave due to chronic illnesses and stress are, in their opinion, the most evident consequences of poor WFB. Chronic illness takes time to develop and is in that sense, a long-term consequence, while stress influences employees in a different manner as its impact is highly dependent on the employee's coping abilities and other circumstances in the individual's life. At the same time, lengthy absence is less costly for an employer than a higher number of shorter absences. In Slovenia, when an employee is absent longer than one month, the entire cost referring to their wages becomes the responsibility of the state. When employers perceive that the consequences of poor possibilities of WFB of their employees are long-term and less costly, their motivation for introducing appropriate instruments to improve this area will continue to be low.

Although, according to employers, greater loyalty to the organization can be expected if WFB of employees is met, it is evidently not perceived as a major trigger for improvement in this area. At the same time, employers in comparison to employees believe increased satisfaction and productivity to be a less probable consequence of good WFB, which in itself again supports the employers' notion of the borderline significance of this area.

\subsubsection{Organizations and Employees with Good Possibilities of Work-Family Balance}

Investigating differences in the perception of consequences in organizations with good possibilities of WFB leads to an important conclusion. There are consequences that are regarded in a similar way by both employees and employers. Both give similar emphasis to stress as a negative consequence of poor WFB of employees. At the same time, both similarly perceive the improved image of the organisation and increased loyalty of its employees resulting from good WFB. Other consequences are perceived differently by the two groups, but the gap between perceptions seem to be smaller, as can be seen from odds ratios that are closer to one than when considering organizations and employees with poor WFB. Therefore, it seems that perception of long term and less costly consequences of poor WFB is not the main reason for neglecting this area as argued earlier, with the reason rather lying in the total lack of agreement between employees and employers regarding consequences leading to the neglect or promotion of this field. The second hypothesis (H2) is therefore supported by the results of the analysis. The perceptions of consequences of employers and employees are more similar in organisations with good possibilities for WFB and completely different in companies with poor possibilities of WFB.

To investigate the motives of organizations regarding WFB further, differences in perceptions of consequences between organizations based on WFB were considered. The results are shown in Table 3. 
Table 3. Comparison of organizations according to WFB: mean (median; standard deviation) agreement with the statement and results of the Mann - Whitney U test

\begin{tabular}{|c|c|c|c|c|}
\hline & WFB & Mean $(\mathrm{Me} ; \mathrm{SD})$ & $\mathrm{U}$ & $\mathrm{P}$ \\
\hline \multirow[t]{2}{*}{ Stress } & good & $3.35(4 ; 0.87)$ & 97790 & 0.02 \\
\hline & poor & $3.21(4 ; 0.93)$ & & \\
\hline \multirow[t]{2}{*}{ Feeling of overwork/burnout } & good & $3.39(4 ; 0.85)$ & 97186 & 0.01 \\
\hline & poor & $3.22(4 ; 0.96)$ & & \\
\hline \multirow[t]{2}{*}{ Conflicts at work/home } & good & $2.95(3 ; 0.9)$ & 97557 & 0.02 \\
\hline & poor & $2.8(3 ; 0.95)$ & & \\
\hline \multirow[t]{2}{*}{ Health problems - frequent acute illnesses } & good & $1.95(2 ; 0.96)$ & 98444 & 0.03 \\
\hline & poor & $1.84(1 ; 1.02)$ & & \\
\hline \multirow[t]{2}{*}{ Lengthy sick leave due to chronic illnesses } & good & $2.9(3 ; 1)$ & 99291 & 0.06 \\
\hline & poor & $2.78(3 ; 1)$ & & \\
\hline \multirow[t]{2}{*}{ Improved image of the organisation } & good & $3.02(3 ; 0.81)$ & 104164 & 0.49 \\
\hline & poor & $2.99(3 ; 0.82)$ & & \\
\hline \multirow[t]{2}{*}{ Improved communication between employees } & good & $3.53(4 ; 0.97)$ & 103699 & 0.42 \\
\hline & poor & $3.48(3 ; 0.95)$ & & \\
\hline \multirow[t]{2}{*}{ Reduced absence due to sick leave } & good & $4.28(4 ; 0.83)$ & 102314 & 0.24 \\
\hline & poor & $4.18(4 ; 0.94)$ & & \\
\hline \multirow[t]{2}{*}{ Increased employee satisfaction and productivity } & good & $3.68(4 ; 1.07)$ & 105185 & 0.67 \\
\hline & poor & $3.64(4 ; 1.11)$ & & \\
\hline \multirow[t]{2}{*}{ Greater loyalty to the organisation } & good & $3.24(3 ; 1.18)$ & 104768 & 0.71 \\
\hline & poor & $3.21(3 ; 1.2)$ & & \\
\hline
\end{tabular}

Source: Research 2011.

Some statistically significant differences between the two groups regarding perceptions of consequences were found and therefore the third hypothesis (H3) can be partially supported by the results. The main differences between organizations having poor and those having good possibilities for WFB lies in the perception of negative consequences deriving from poor WFB. Organizations with good possibilities for WFB place greater importance on the negative consequences of poor WFB, namely stress, burnout, conflicts and frequent health issues of employees than organizations with poor possibilities for WFB.

\subsection{Discussion}

The first aim of this paper was to examine the most evident negative consequences of work-family imbalance and the most positive consequences of work-family balance (hypotheses H1a and H1b), where both the perceptions of employers and employees were compared. The feeling of burnout and stress emerged as the most important negative consequence of work-family imbalance from employees' and employers' point of view. Conflicts at work and/or at home also tend to manifest themselves more frequently when an imbalance is present. Positive consequences of WFB, according to employers, are manifested primarily in reduced absence from work due to the sick leave, secondarily, by increased employee satisfaction and productivity and thirdly, in improved communication between employees. These results were expected since the authors in the literature review had mentioned identical or similar consequences, either positive or negative (e.g., Parasuraman/Greenhaus, 2002; Lockwood, 2003; Dallimore \& Mickel, 2006; Haemmig \& Bauer, 2009; Baxter \& Chesters, 2011).

Interestingly, employers on one hand perceive illnesses as the consequence of imbalance as less important, and on the other, less frequent absence due to sick leave as the most important consequence of balance. The results seem a bit contradictory however less frequent absences could also be a consequence of other factors apart from health issues, such as different private errands employees need to fulfil at the expense of work time when confronted with work-family imbalance.

It is a general observation that the positive consequences provoked greater agreement with the claims in both 
groups. This may be because positive claims are socially more acceptable than negative ones (social desirability bias).

The second aim was to compare employer and employee perceptions of the consequences of work-family (im)balance when employees experience poor WFB and organizations offer poor possibilities for WFB and when employees experience good WFB and organizations offer good possibilities for WFB (hypothesis H2). The results showed that the organisations with poor possibilities of work-family balance and employees experiencing work-family imbalance themselves significantly differ in their perception of all consequences of work life balance and work-life imbalance. On the other hand, the difference in perceptions is much smaller when comparing those organisations with good possibilities of work-family balance and employees experiencing work-family balance themselves. Results suggest that the communication gap between employees and employers in organisations with poor WFB is much higher than in organisations with good WFB. If employers are unaware of the consequences of the WF(im)B, they cannot act upon them and improve the situation of their employees. At the same time, employers in organizations with poor WFB of employees perceive consequences of WF(im)B as long-term and less costly, which is in line with the findings of other authors (Lockwood, 2003; Kisilewitz \& Bedington, 2009; McGuire, Kenney \& Brashler, 2010). This too, leads to a state of neglect in the area of employee WFB.

To conclude the comparisons, the third aim was achieved upon comparing the organizations with poor possibilities of WFB and organizations with good possibilities of WFB regarding the perception of consequences of work-family (im)balance (hypothesis H3). The results showed that the organizations offering good possibilities for WFB assess the negative consequences of poor WFB, e.g. stress, burnout, conflicts and frequent health issues of employees as more important than organizations with poor possibilities for WFB. This indicates that there are significant differences in the organizational cultures of different organizations and that it is management, who plays an important role in deciding whether or not to empower WFB through numerous measures and policies and contribute to positive consequences for all stakeholders - employees, employers and the wider society. The findings are similar to those of Matthews, Bulger, Barnes-Farrell (2010), Michael (2010) or Sieger and Wiese (2009) who found the social support of employers (managers) to be one of the key factors for reducing work-family conflict.

\section{Conclusions and Suggestions for Further Research}

The study which considered the circumstances related to balancing the work and family realms in Slovenian organisations showed that employers and employees recognize the same negative consequences of work-family imbalance and the same positive consequences of work-family balance. But as the results show, the ranking of the enumerated consequences was slightly different when comparing both groups of stakeholders.

The results also partially confirmed our assumption regarding the differences in perception of work-family balance or imbalance by employers and employees and between the different groups of employers. Due to the differences in perceptions of the consequences of WF(im)B between employers and employees, it would be useful for both parties to establish and maintain a dialogue in order to come closer to understanding the needs for and benefits of different measures that could support employees in balancing their work and family lives. If employees expect their employers to offer or assure a more WFB-friendly working environment, they should communicate this need to the employer. Otherwise, they cannot expect the employer to detect all of their needs and requirements and, consequently, introduce policies and measures for an efficient WFB. On the other hand, the employers should attend various workshops or other types of trainings to gain knowledge of the possibilities and benefits of assuring a working environment where employees could efficiently balance their work and family lives. The results show that the employers with poor possibilities of WFB are not aware of the negative consequences of work-life imbalance, which can result in both financial and non-financial as well as short- and long-term consequences with negative impacts on the employer, employee and wider society.

The results of the research can be applied to both the field and in practice in several ways. The first comparison of perceptions of the most important groups of stakeholders, directly interested and involved in balancing work and family can aid the field while the findings of the study will prove especially useful to company owners and top managers in practice, especially for those who have so far not been aware of how important the concept of balancing work and family can be for the performance of their organisations. Thus, we expect our findings to significantly contribute to improvements in knowledge and efforts in the field of work-life balance.

Owners and managers should give more attention to WFB, since stressed-out, burned-out or dissatisfied employees can result in direct or indirect costs attributed to absenteeism, turnover, low motivation, morale and commitment with a variety of side effects also for the wider society. In order to avoid the negative consequences 
of stress and burnout resulting from work-family imbalance, employees, employers, trade unions, local communities and the state must all seek long-term solutions to finding balance, both for individuals and for the society as a whole. Dialogue between state and local administrations, managers of private and public organisations, and employees and their representatives is important when developing practices to facilitate the balancing of work and family lives so that they are tailored to the needs of all stakeholders. Making the working environment family-friendly is most effective when it is seen as a shared responsibility. It is also vital that policies/measures be actually implemented, and not merely formulated.

Key factors in improving the field of WFB thus include better communication, the joint setting of goals and the long-term motivation of all stakeholders in realising measures to improve the situation in this field. It is essential to define responsible bodies and set deadlines for the implementation of individual solutions, set up a system of communication to coordinate the introduction of solutions, and establish systems to disseminate good practices among employers, raise employees' awareness and train them for healthy physical and mental well-being. Attention to WFB must be an ongoing and evolving process. The ongoing verification and evaluation of existing measures is essential, since the needs of employees and the objectives of employers, as well as the external environment, are constantly changing.

As seen from the research within the INODEL project, it was evident that the motivation of employers to contribute to the WFB of their employees lies primarily in the perception it will be cost beneficial for the organisation. Further research in evaluating costs of employees' work-family imbalances to organisations' business results should be carried out. Current research is focused primarily on the opinions of the two stakeholders rather than also on measurable factors such as actual number and length of absences in companies. It is evident that consequences of work family imbalance should be measured in units easily convertible into company costs thereby resulting in a language employers understand most. Only by doing so and presumably establishing that costs are indeed higher in companies with poorer possibilities of WFB of their employees, will employers be motivated to give more attention to this area and consequently, contribute to their employees' satisfaction and quality of life.

Further research is also required to examine whether the results are applicable across a larger and more representative sample and between employees and employers' representatives from the same organizations. International and time-based comparisons would also contribute to a more thorough understanding of the area.

\section{References}

Agresti, A. (2007). Building and applying logistic regression models. An Introduction to Categorical Data Analysis. Hoboken, New Jersey: Wiley-Interscience. http://dx.doi.org/10.1002/0470114754

Allen, T. D. (2001). Family-supportive work environments: The Role of Organizational Perceptions. Journal of Vocational Behavior, 58, 414-435. http://dx.doi.org/10.1006/jvbe.2000.1774

Aristovnik, A., \& Pungartnik, A. (2009). Analysis of reaching the Lisbon Strategy targets at the national level: the EU-27 and Slovenia. The Transylvanian Review of Administrative Sciences, 27E, 5-21.

Ashforth, B. E., Kreiner, G. E., \& Fugate, M. (2000). All in a day's work: Boundaries and micro role transitions. Academy of Management Review, 25, 472-563.

Baxter, J., \& Chesters, J. (2011). Perceptions of Work-Family Balance: How Effective are Family Friendly Policies? Australian Journal of Labour Economics, 14(2), 139-151.

Behson, S. J. (2005). The relative contribution of formal and informal organizational work-family support. Journal of Vocational Behavior, 66, 487-500. http://dx.doi.org/10.1016/j.jvb.2004.02.004

Beutell, N., \& Wittig-Berman, U. (1999). Predictors of work-family conflict and satisfaction with family, job, career, and life. Psychological Report, 85, 893-903. http://dx.doi.org/10.2466/pr0.1999.85.3.893

Bird, J. (2006). Work-life Balance - Doing it Right and Avoiding Pitfalls. Employment Relations, 33, 21-30. http://dx.doi.org/10.1002/ert.20114

Bourne, K. A., Wilson, F., Lester, S. W., \& Kickul, J. (2009). Embracing the Whole Individual: Advantages of Dual-centric Perspective of Work and Life. Business Horizons, 52, 387-398. http://dx.doi.org/10.1016/j.bushor.2009.04.001

Boyar, S. L., Maertz, C. P. Jr, \& Allison, W. P. (2003). The effects of work-family conflict and family-work conflict on non-attendance behaviours. Journal of Business Research, 58, 919-925. http://dx.doi.org/10.1016/j.jbusres.2003.11.005 
Breaugh, J. A., \& Frye, N. K. (2007). An examination of antecedents and consequences of the use of family-friendly benefits. Journal of Management Issues, 19(1), 35-52.

Byron, K. (2005). A meta-analytic review of work-family conflict and its antecedents. Journal of Vocational Behavior, 67, 169-198. http://dx.doi.org/10.1016/j.jvb.2004.08.009

Casper, W. J., \& Buffardi, L. C. (2004). Work-life benefits and job pursuit intensions: The role of anticipated organizational support. Journal of Vocational Behavior, 65, 391-410. http://dx.doi.org/10.1016/j.jvb.2003.09.003

Casper, W. J., Harris, C., Taylor-Bianco, A., \& Wayne, J. H. (2011). Work-family conflict, perceived supervisor support and organizational commitment among Brazilian professionals. Journal of Vocational Behavior, 79, 640-625. http://dx.doi.org/10.1016/j.jvb.2011.04.011

Clark, S. C. (2000). Work/family border theory: A new theory of work/family balance. Human Relations, 53, 747-817. http://dx.doi.org/10.1177/0018726700536001

Clark, S. C. (2001). Work cultures and work/family balance. Journal of Vocational Behavior, 58, 348-365. http://dx.doi.org/10.1006/jvbe.2000.1759

COFACE (Confederation of Family Organizations in the European Union). (2008). COFACE Position on reconciling family life, private life and professional life to prevent poverty and social exclusion. Retrieved (September 2011) from http://coface-eu.org/en/upload/WG\%20SOCIAL/WG1-2008-PositionCOFACE-reconciliation-EN.pdf

Commission of the European Communities. (2008). Implementation of the Barcelona objectives concerning childcare facilities for pre-school-age children. Retrieved (January 2012) from http://ec.europa.eu/social/BlobServlet?docId=604\&langId=en

Dallimore, E., \& Mickel, A. (2006). Quality of life: Obstacles, advice, and employer assistance. Human Relations, 59, 61-103. http://dx.doi.org/10.1177/0018726706062759

Darmanin, M. (2006). Introduction of family-friendly measures at the workplace. Research report for National Commission for the Promotion of Equality (NPCE). Retrieved (October 2011) from http://www.equality.gov.mt/filebank/documents/FINAL\%20Family\%20Friendly\%20Measures\%20Report\% 202007\%2002\%2002.pdf

De Villers, J., \& Kotze, E. (2003). Work-life balance: A study in the petroleum industry. SA Journal of Human Resource Management, 1, 15-23.

Dench, S., Bevan, S., Tamkin, P., \& Cummings, J. (2000). Family-friendly employment: Its importance to small and medium enterprises. Labour Market Trends, 108(3), 111-120.

Doorne-Huiskes, A., Remery, C., \& Schippers, J. (2003). Family-friendly policies in the Netherlands. Utrecht: Utrecht University.

Dune, H., \& Teg, C. (2007). Putting Balance into Business-Worklife balance as a business strategy for avoiding brain drain. Strategic HR Review, 6, 28-31. http://dx.doi.org/10.1108/14754390780001014

European Commission. (2010). A strategy for smart, sustainable and inclusive growth. COM (2010) 2020 final. Retrieved November, 2012 from http://europa.eu/legislation_summaries/employment_and_social_policy/eu2020/em0028_en.htm

Friedman, S. D., \& Greenhaus, J. H. (2000). Work and family - Allies or enemies? What happens when business professionals confront life choices. New York: Oxford University Press. http://dx.doi.org/10.1093/acprof:oso/9780195112757.001.0001

Frone, M. R. (2003). Work-family balance. In Quick, J. C., \& Tetrick, L. E. (Eds.), Handbook of occupational health psychology (pp. 143-162). Washington, DC: American Psychological Association. http://dx.doi.org/10.1037/10474-007

Garson, G. D. (2012). Binomial and Multinomial Logistic Regression. Retrieved April 2012, from http://faculty.chass.ncsu.edu/garson/PA765/logistic.bak

Gray, M., \& Tudball, J. (2002). Family-Friendly Work practicies: Differences Within and Between Workplaces. Melbourne: Australian Institue of Family Studies. Retrieved March, 2012 from http://www.aifs.gov.au/institute/pubs/fm2002/fm61/mg2.pdf

Greenhaus, J. H., \& Allen, T. D. (2011). Work-family balance: A review and extension of the literature. In Quick, 
J. C., \& Tetrick, L. E. (Eds.), Handbook of occupational health psychology (2nd ed.). Washington, DC: American Psychological Association.

Greenhaus, J. H., Collins, K. M., \& Shaw, J. D. (2003). The relation between work-family balance and quality of life. Journal of Vocational Behavior, 63, 510-531. http://dx.doi.org/10.1016/S0001-8791(02)00042-8

Greenhaus, J. H., Parasuraman, S., \& Collins, K. M. (2001). Career involvement and family involvement as moderatos of relationships between work-family conflict and withdrawal from a profession. Journal of Occupational Health Psychology, 6, 91-100. http://dx.doi.org/10.1037/1076-8998.6.2.91

Grzywacz, J. G., \& Bass, B. L. (2003). Work, family and mental health: Testing different models of work-family fit. Journal of Marriage and Family, 65, 248-262. http://dx.doi.org/10.1111/j.1741-3737.2003.00248.x

Grzywacz, J. G., \& Carlson, D. S. (2007). Conceptualizing work-family balance: Implications for practice and research. Advances in Developing Human Resources, 9, 455-471. http://dx.doi.org/10.1177/1523422307305487

Haemmig, O., \& Bauer, G. (2009). Work-life imbalance and mental health among male and female employees in Switzerland. International Journal of Public Health, 88-95. http://dx.doi.org/10.1007/s00038-009-8031-7

Halpern, D. F. (2005). How time-flexible work policies can reduce stress, improve health, and save money. Stress and Health, 21, 157-168. http://dx.doi.org/10.1002/smi.1049

Hyland, M. M., Rowsome, C., \& Rowsome, E. (2005). The integrative effects of flexible work arrangements and preferences for segmenting or integrating work and home roles. Journal of Behavioral and Applied Management, 6, 141-160.

ILO. (2004). The 'family-friendly' workplace. Geneva: International Labour Office. Retrieved (February 2012) from http://www.ilo.org/public/english/protection/condtrav/pdf/infosheets/wf-3.pdf

Iverson, R. D., \& Derry, S. J. (2001). Understanding the personological basis of employee withdrawal: the influence of affective disposition on employee tardiness, early departure, and absenteeism. Journal of Applied Psychology, 86, 856-922. http://dx.doi.org/10.1037/0021-9010.86.5.856

Jansen, N. W. H., Kant, I. J., Kristensen, T. S., \& Nijhuis, F. J. N (2003). Antecedents and Consequences of Work-Family Conflict: A prospective Cohort Study. Journal of Occupational Environment Medicine, 45, 479-491. http://dx.doi.org/10.1097/01.jom.0000063626.37065.e8

Jones, F., Burke, R. J., \& Westman, M. (2005). Work-life balance: A psychological perspective. East Sussex, UK: Psychology Press.

Kelly, E. L., Kossek, E. E., Hammer, L. B., Durham, M., Bray, J., Chermack, K., Murphy, L. A., \& Kaskubar, D. (2008). Getting There from Here: Research on the Effects of Work-Family Initiatives on Work-Family Conflict and Business Outcomes. Acad. Manag. Ann., 305-349. http://dx.doi.org/10.1080/19416520802211610

Kisilewitz, M., \& Bedington, T. (2009). Managing Work-life Balance Programs in a Down Economy. Benefits and Compensation Digest. International Foundation for Employee Benefit Plans, 31-34.

Knaflič, T., Svetina Nabergoj, A., \& Pahor, M. (2010). Analiza učinkov uvajanja družini prijaznega delovnega okolja (Analysis of effects of introducing family-friendly working environment). Economic and Business Review, 12, 27-44.

Lapierre, L. M., Spector, P. E., Allen, T. D., Poelmans, S., Cooper, C. L., O'Driscoll, M. P., Sanchez, J. I., Brough, P., \& Kinnunen, U. (2008). Family-supportive organization perceptions, multiple dimensions of work-family conflict, and employee satisfaction: A test of model across five samples. Journal of Vocational Behavior, 73, 92-106. http://dx.doi.org/10.1016/j.jvb.2008.02.001

Levin-Epstein, J. (2006). Getting Punched: The Job and Family Clock. Washington: Center for Law and Social Policy. Retrieved (January 2012) from http://www.clasp.org/admin/site/publications/files/0303.pdf

Littig, B. (2008). Work Life Balance - catchword or catalyst for sustainable work? Institute for Advanced Studies. Vienna. Retrieved (March 2012) from http://www.ihs.ac.at/publications/soc/rs85.pdf

Lockwood, N. R. (2003). Work/life balance: Challenges and solutions. SHRM Knowledge Center. Retrieved (November 2012) from http://www.shrm.org/searchcenter/Pages/Results.aspx?k=lockwood\%202003

Matsuda, Y., Kokumai, M., \& Wang, J. (2009). Reports on survey for work-life balance in Japanese companies. Okayama Economic Review, 41, 55-76. 
Matthews, R. A., Bulger, C. A., \& Barnes-Farrell, J. L. (2010). Work social supports, role stressors, and work-family conflict: The moderating effect of age. Journal of Vocational Behavior, 76, 78-90. http://dx.doi.org/10.1016/j.jvb.2009.06.011

McGuire, J. F., Kenney, K., \& Brashler, P. (2010). Workplace flexibility 2010. Flexible Work Arrangements: The Fact Sheet. Northern University, Bouve College of Health Sciences. Retrieved (October 2011) from http://workplaceflexibility2010.org/images/uploads/FWA_FactSheet.pdf

McMillan, H. S., Morris, M. L., \& Atchley, E. K. (2011). Constructs of the Work/Life interface: A Synthesis of the Literature and Introduction of the Concept of Work/Life Harmony. Human Resources Development Review, 10, 6-25. http://dx.doi.org/10.1177/1534484310384958

Michael, J. S., Mitchelson, J. S., Pichler, S., \& Cullen, K. L. (2010). Clarifying relationships among work and family social support, stressors, and work-family conflict. Journal of Vocational Behavior, 76, 91-104. http://dx.doi.org/10.1016/j.jvb.2009.05.007

Ministry of Community Development, Youth and Sports - MCYS. (2004). Singapore Family Friendly Employer $\begin{array}{llll}\text { Award Presentation. } & \text { Retrieved } & \text { March, } & 2012 \text { from }\end{array}$ http://app1.mcys.gov.sg/PressRoom/SingaporeFamilyFriendlyEmployerAwardPresentat.aspx

Morgan, L. R., Marschke, E., \& Segal, S. (2009). Work Life Balance a Contemporary Topic: How do Marketing Practitioners Deal with Organizational Support Issues? The Academy of Business Disciplines Publication. Retrieved May, 2013 from http://www.researchgate.net/publication/228473242_Work_Life_Balance_a_Contemporary_Topic_How_do _Marketing_Practitioners_Deal_with_Organizational_Support_Issues

Nelson, C. C., Li, Y., Sorensen, G. \& Berkman, L. F. (2012). Assessing the Relationship between Work-Family Conflict and Smoking. American Journal of Public Health, 9, 1767-1772. http://dx.doi.org/10.2105/AJPH.2011.300413

Obadić, A., \& Aristovnik, A. (2011). Relative efficiency of higher education in Croatia and Slovenia: an international comparison. Amfiteatru Economic, 30, 362-376.

OECD. (2008). Babies and Bosses: Balancing Work and Family Life. OECD Observer. Retrieved January, 2012 from http://www.oecd.org/dataoecd/12/2/34566853.pdf

Parasuraman, S., \& Greenhaus, J. H. (2002). Toward reducing some critical gaps in work-family research. Human Resource Management Review, 12, 299-312. http://dx.doi.org/10.1016/S1053-4822(02)00062-1

Peduzzi, P., Concato, J., Kemper, E., Holford, T. R., \& Feinstein, A. R. (1996). A Simulation Study of the Number of Events per Variable in Logistic Regression Analysis. J. Clin Epidemiol, 49(12), 1373-1379. http://dx.doi.org/10.1016/S0895-4356(96)00236-3

Saltzstein, A. L., Ting, Y., \& Salzstein, G. H. (2001). Work-family balance and job satisfaction. Public Administration Review, 61, 452-466. http://dx.doi.org/10.1111/0033-3352.00049

Sands, J., \& Harper, T. (2004). Family-friendly benefits and organizational performance. Business Renaissance Quarterly, 2, 107-126.

Schmiedel, V. (2011). Izgorelost/Burnout: ko nas delo, družina in vsakdanjih izčrpavajo. Maribor: Mettis Bukvarna.

Sieger, C. P., \& Wiese, B. S. (2009). Social support from work and family domains as an antecedent of moderator of work-family conflict. Journal of Vocational Behavior, 75, 26-37. http://dx.doi.org/10.1016/j.jvb.2009.03.001

SURS. (2009). SI - STAT podatkovni portal Statističnega urada Republike Slovenije. Retrieved March, 2012 from http://pxweb.stat.si/pxweb/dialog/statfile2.asp

SURS. (2010). SI - STAT podatkovni portal Statističnega urada Republike Slovenije. Retrieved March, 2012 from http://pxweb.stat.si/pxweb/dialog/statfile2.asp

Švab, A. (2007). Combining Work and Family Life in Slovenia: An Ethic of care perspective for normative policy analysis. Društvena istraživanja, 16(4-5), 965-987.

Tariq, A., Aslam, H. D., Siddique A., \& Tanveer, A. (2012). Work-life Balance as a Best Practice Model of Human Resource Management: A Win-Win Situational Tool for the Employees and Organizations. Mediterranean Journal of Social Sciences, 3, 577-585. 
Taylor, R. (2003). The Future of Work-Life Balance. Economic \& Social Research Council. Retrieved April, 2012 from http://www.esrc.ac.uk/_images/future_of_work_life_balance_tcm8-13554.pdf

The Lattice group. (2010). The Lattice talks. Work-Life balance. An issue book. Retrieved September, 2011 from http://www.nifi.org/stream_document.aspx?rID=10816\&catID=15\&itemID=10813\&typeID=8

Thévenon, O. (2008). Family policies in Europe: available databases and initial comparisons. Vienna: Yearbook of Population Research 2008. Retrieved (April 2011) from http://epub.oeaw.ac.at/0xc1aa500d_0x001c9ea5.pdf

Ueda, Y. (2012). The Effects of the Perception of Work-life Balance on Acceptance of Work Arrangement Requests. International Business Research, 5, 24-33. http://dx.doi.org/10.5539/ibr.v5n8p24

Valcour, M. (2007). Work-based resources as moderators of the relationship between work hours and satisfaction with work-family balance. Journal of Applied Psychology, 92, 1512-1523. http://dx.doi.org/10.1037/0021-9010.92.6.1512

Whittard, J., \& Burgess, J. (2007). Working-time flexibility and full-time work in retail banking organisation. Labour \& Industry, 17(3), 119-141. http://dx.doi.org/10.1080/10301763.2007.10669354

Work \& Family Connection. (2005). The Most Important Work-Life-Related Studies. Retrieved November, 2012 from http//www.workfamily.com

Žaucer Šefman, B. (2007). Gradivo za medije razvojnega partnerstva Mladim materam/družinam prijazno zaposlovanje. Zavod Ekvilib.

\section{Notes}

Note 1. SURS 2009.

Note 2. SURS 2010, Economically active population.

\section{Appendix}

Appendix A. Testing differences between expressiveness of pairs of consequences among employers (Wilcoxon's test)

\begin{tabular}{lcc}
\hline & Z & P value \\
\hline Feeling of overwork/burnout - stress & $-2.177^{\mathrm{a}}$ & .030 \\
Conflicts - stress & $-14.929^{\mathrm{b}}$ & .000 \\
Conflicts - lengthy sick leave due to chronic illnesses & $-1.069^{\mathrm{a}}$ & .285 \\
Lengthy sick leave due to chronic illnesses - frequent acute illnesses & $-23.036^{\mathrm{a}}$ & .000 \\
Increased employee satisfaction and productivity - reduced absenteeism due to sick leave & $-13.191^{\mathrm{b}}$ & .000 \\
Improved commun. between employees - increased employee satisfaction and productivity & $-3.352^{\mathrm{b}}$ & .001 \\
Greater loyalty to the organisation - improved communications between employees & $-5.955^{\mathrm{b}}$ & .000 \\
Improved image of the organisation - greater loyalty to the organisation & $-4.691^{\mathrm{b}}$ & .000 \\
\hline
\end{tabular}

Appendix B. Testing differences between expressiveness of pairs of consequences among employees (Wilcoxon's test)

\begin{tabular}{|c|c|c|}
\hline & $\mathrm{Z}$ & $\mathrm{P}$ value \\
\hline Feeling of overwork/burnout - stress & $-.956^{\mathrm{a}}$ & .339 \\
\hline Conflicts - stress & $-.996^{\mathrm{b}}$ & .319 \\
\hline Conflicts - lengthy sick leave due to chronic illnesses & $-18.207^{\mathrm{a}}$ & .000 \\
\hline Lengthy sick leave due to chronic illnesses - frequent acute illnesses & $-15.025^{\mathrm{b}}$ & .000 \\
\hline Improved commun. between employees - increased employee satisfaction and productivity & $-2.495^{b}$ & .013 \\
\hline Greater loyalty to the organisation - improved communication between employees & $-17.373^{b}$ & .000 \\
\hline Improved image of the organisation - greater loyalty to the organisation & $-2.007^{\mathrm{b}}$ & .045 \\
\hline Improved communication between employees - reduced absenteeism due to sick leave & -13.789 & .000 \\
\hline
\end{tabular}




\section{Copyrights}

Copyright for this article is retained by the author(s), with first publication rights granted to the journal.

This is an open-access article distributed under the terms and conditions of the Creative Commons Attribution license (http://creativecommons.org/licenses/by/3.0/). 